\title{
Strategy and Business Survival during Disruptive Times: A Survey of Passenger Transporters in Harare, Zimbabwe during the COVID-19 Lockdown
}

\author{
Ruth T. Mugweni \\ Founder and Director, Kurainashe Non-governmental Organisation, Zimbabwe
}

\begin{abstract}
Business leaders must be strategic about their operations to ensure success in different operating environments. The COVID-19, which emerged as a public health pandemic that affected businesses in different sectors differently. Passenger transport businesses were directly affected after the movement of people was banned for extended periods, during the lockdowns. The lockdowns represented a disruption in the operating environments. The study sought to assess the effect of strategic management on the survival of passenger transport operators during the COVID-19 induced lockdown disruptions in Harare, Zimbabwe. Data were collected using survey questionnaires distributed to representatives of 100 passenger transporters in Harare, from which questionnaires were returned. Results showed that 84 percent of the passenger transport operators have formal organizational structures of which about 73 confirmed the practice of strategic planning. Therefore, there is high adoption of strategic management by passenger transport operators in Harare. The most effective strategies for enhancing business survival in disruptions are diversification and competitive strategies. The logistic regression model results showed that the existence of a formal structure minimized the negative impact of the COVID-19 lockdown disruptions on the survival of passenger transport operators in Harare.
\end{abstract}

Keywords: Business Survival, COVID-19, Lockdown, Passenger Transport Operators, Strategy, Zimbabwe.

\section{Introduction}

Towards the end of 2019, the Chinese city of Wuhan in Hubei province reported a new respiratory infection called the novel coronavirus (nCoV). The virus caused the disease now named Corona Virus Disease 2019 (COVID-19). Within three months of the discovery of the disease, it had spread to virtually all the continents, such that by the end of March 2020, the world came to a standstill through the introduction of national lockdowns meant to slow down the spreading of the $\mathrm{nCoV}$ and the resultant COVID-19 [1]. The lockdowns were a temporary measure meant to minimise interactions between people to curb the spread of COVID-19 since there was no cure for the disease. The COVID-19 became a global public health pandemic and disrupted economic activity through these national lockdowns [2]. The lockdowns amounted to a major disruption to the operations of most businesses of different sizes in different sectors of the economy, with passenger transportation businesses being one of the worst affected since public transport was banned for both domestic and international travel.

This disruption and the resultant turbulence inevitably had an impact on all business organisations of all sizes. The consequences of economic disruption are exacerbated by the strategies that the organisation had been pursuing or the absence of such strategies [2]. The global economic effect of the COVID-19 related disruptions is still under consideration 
with such organisations as the OECD and the UNCTAD estimating a substantial impact on supply chains and on economic activity with the global economic growth forecast to shrink by not less than 2.5 percent of global gross domestic production. For developing countries, such as Zimbabwe, that rely more on the importation of goods and with most of the people relying on cross-border trade for survival, the impact is expected to be much higher [3]. The passenger transport operators, ferrying both intercity and cross border passengers, were negatively affected by the lockdowns, which have remained in force for an indefinite period, however, intercity transport services are operational.

The direct effect of the lockdowns on some business organisations is the imminent closure of the business due to extended periods of lockdowns. Most businesses have been operating for months without earning any revenue, yet they were incurring fixed expenses without any commensurate way of defraying these costs [2]. Such disruptive times require strategic management with sustainable strategies have been in place for such disruptive times as caused by the COVID-19 induced lockdowns [4]. Most of the passenger transport operators in Zimbabwe are run as micro, small or medium enterprises (MSMEs). It is therefore imperative to contextualize how the passenger transport operators have been affected by the COVID-19 disruptions and how strategic management could have helped the businesses to survive.

Small to medium-sized businesses play significant roles in economies of both developed and developing countries, including such countries as the United States economy, by creating jobs and driving innovation [5]. There are a variety of definitions of MSMEs which depend on the size of the enterprises measured in terms of the number of employees, annual turnover, and balance sheet sizes [6]. Due to the sizes of most MSMEs, they usually have challenges in having the skill set necessary for implementing strategic management [4]. The lack of skills is usually due to the businesses being operated or managed by the entrepreneurs (owners) who may carry the vision for their enterprise but lacks strategic management skills.

As owners of businesses, there is a need to think through how to adapt to changes in the environment and meet the specific needs of their organizations as dictated by either their internal circumstances or the external operating environment [7]. It is imperative to establish how passenger transport operators have been able to implement strategic management for the purpose of ensuring businesses survival. The COVID-19 induced disruption to passenger travel in Zimbabwe has affected the operations of the passenger transport operators [8].

\section{Research Problem Statement}

The Government of Zimbabwe instituted an initial national lockdown as a response to the COVID-19 pandemic on $30^{\text {th }}$ of March 2020, and the lockdown is continuing [8]. During this lockdown, only businesses providing essential services have been allowed to continue operating throughout the period of disruption of business operations, whilst other business operations remain banned. One of the sectors that have remained not operating to full capacity in terms of the lockdown regulations is the provision of public transport services by private operators. Only public provision of transport services is operational within and between towns and cities, yet cross-border passenger transportation contributes significantly to Zimbabwe's informal sector economy has remained restricted. The study, therefore, interrogates how strategic management has affected the survival of passenger transport operators in Zimbabwe's capital city of Harare, given the extended periods of the national lockdown, which has left these businesses not operational.

\section{Review of Related Literature}

This section reviews literature related to the study as guided by the variables in the research problem highlighted above. The literature review is related to the importance of strategic 
management in organisations in different sectors and for businesses of different sizes.

Strategic management is defined as the art and science of formulating, implementing, and evaluating decisions that cut across the entire organisation for purposes of exploiting and creating new and different opportunities for tomorrow [9]. Whilst the concept of strategy is defined by [10] as "management's action plan for running the business and conducting operations". Further to this, "a company's strategy consists of the competitive moves and business approaches that managers are employing to grow the business, attract and please customers, compete successfully, conduct operations, and achieve the targeted levels of organizational performance" [10]. Strategic management, therefore, includes processes such as scanning the environment, formulation of the strategy, implementation and monitoring of strategy, evaluation, and review of the process of implementing the organisation's strategy for purposes of ensuring the achievement of the business' long-term objectives effectively and efficiently.

The key issues organisations should focus on during the crafting and execution of strategy are captured by Mintzberg cited by [11] as follows:

"Strategy depends on basic building blocks, which are used in the attack, defence and manoeuvre. Strategy-making relies on finding and executing new combinations of these blocks. In every age, technology and social organization limit the combinations. After some time, these limits seem inevitable and hence natural. Strategists cease to question received wisdom and confine themselves to variations on accepted themes. Therefore, it is left to the great commanders, such as Napoleon, to innovate strategically by recognizing and bringing about new combinations" [11].

Overall, business strategy is the outcome of the decisions made by business owners and/or managers to guide the business on the environment, structure, and processes that influence the business's survival [12]. The business strategy entails the concept of strategic planning, which is defined as the process by which an organization makes decisions and takes actions to enhance its long-term performance [13]. The business strategy sets a pattern of objectives, purposes, and goals for the business [11]. Owners and managers should design different approaches to achieve their strategic goals. Four generic business competitive strategies that are earlier identified by Porter as also identified as follows [14]:

a) Differentiation strategy,

b) Cost leadership strategy,

c) Focus strategy, and

d) Hybrid strategy.

For small businesses, there are four strategy types that have been pursued by profitable small firms, that is niche, defender, prospector, and differentiation [14]. Businesses must therefore select the strategy that best suits their organisational goals and the organization's size. In Zimbabwe, business size is measured in terms of the number of employees, annual turnover, and the value of assets [6].

Business strategy emerges as business owners and managers attempt to solve problems arising during the operation of their businesses, and they allocate resources to meet their business needs [15]. An examination of how young and established business entities approached strategic orientation was done [16]. Strategies developed and pursued by business organisations should ultimately achieve the survival of their enterprise both in the short-term and in the long-term [17]. Thus, the survival of the business is a strategic outcome of the actions an enterprise deploys in their day-to-day operations, which ensure the success of the enterprise despite the context and environment in which the business operates in [18]. Therefore, during disruptive times management ought to carefully adjust and adapt their business strategy to ensure longevity in the survival of their business entities.

Traditionally, disruptions in businesses have been caused by the introduction of new 
technologies. Scholarly works are tracked back to the writings of Christensen, who introduced the phrase "disruptive technological change" in a seminal work titled "Innovator's Dilemma". According to [19], disruptive technologies have resulted in those firms better strategically positioned to deal with such disruptions becoming market leaders whilst other businesses have seen their demise resulting from such disruptive technologies. It is these disruptive technologies that resulted in the creation of such giants as Amazon.com that took advantage of the innovation of the world wide web (www) to develop web-based bookstores instead of the traditional brick and mortar bookstores [20]. The Amazon.com business continued growing and because of their strategic ability to ride on the internet, technological disruption led to the business to become a leader in their business sector [20]. It is therefore important for businesses to have viable business models and strategies to take advantage of disruptions.

The difference between successful and failed businesses due to the disruptions caused by technological change can only be explained in terms of the strategy that the entities employed. According to [21], the basic challenge of technological changes is that they often happen much faster than people, organizations, or societies can adapt. It is these technology-based disruptions that led to changes in global economies, now known as the industrial revolution [22]. Literature shows that the concept of disruptions in relation to strategy and management emanated from the introduction of new technologies that resulted in changes in the business operating environment [23]. The operating environment and, ultimately, the strategy of any business is affected by other disruptions that affect the markets [17]. It is, however, noted that innovations and disruptive changes have been and continue to be one of the driving forces behind the survival of humans and their creations, such as business enterprises [22]. The COVID-19 pandemic is a disruption that affected the way businesses are run across the globe [4].

Research illustrates that "the original concept of disruption, in its many variations, can be defined as a changing force for strategic management" [24]. Not only is disruption potentially altering the basis for competition for current organizations in several ways. Disruption also forces strategic management researchers to change their conceptions of strategy, strategic management, and strategy processes to reflect a new managerial landscape created by disruption [24]. The concept of disruptions has changed over time since the nature of changes and disruptions in the environment have changed [23]. Thus, the concept of disruption is not a fixed and static concept, instead, the concept is still emerging and evolving, as highlighted that in its original state, it focused on technological disruptions but have since evolved to include other disruptions. The following are some of the technological developments that still drive disruptions; digitalization, Big Data, and Industry 4.0 [24].

Business failure is usually anchored on the enterprises leader's failure to understand the complexity and dynamics of their business model, lack of innovation and creativity, as well as the inability to execute their strategies [25]. The financial crisis of 2008-2009, for example, rendered many businesses outmoded, and organizations throughout the world were plunged into turbulent economic environments [26]. At the same time, rapid changes continued unfolding as technological developments like social media exploded [27, 28] and global disasters disrupted lives, economies, and businesses, among many other facets of life [17, 18]. In 2020 came a global health pandemic that virtually disrupted all systems around the globe, such as international travel, business activities, and national borders were locked down [4].

Organizations must therefore deal with disruptions effectively to ensure their business 
entities survive. Otherwise, failure is unavoidable [18]. Thus, there is a need for business transformation to guarantee the survival and success of business entities. There are several factors that ensure the transformation manoeuvres the disruptions effectively, and these include business leaders must make their organizations better focus on the customer and build businesses that are committed to innovation and can act with agility [25]. Therefore, business leaders must be strategic and adapt to changes in the environment. The Texila Module on Strategic Management emphasises on strategic leadership, where leaders must manoeuvre an ambiguous environment [29]. Such leaders should create apposite organizational structures, allocate resources, and share the organizational vision and mission.

Given the extent to which most passenger transport operator companies in Zimbabwe were affected by the COVID-19 disruption, it is imperative to establish how strategic management or the lack thereof has impacted on the survival of these critical players in Zimbabwe's economic landscape. This evaluation is essential during the economy-wide disruptions caused by the COVID-19 pandemic and the resultant national lockdowns. Without proper strategies, in place, passenger transport operators are likely to be outpaced by the environment leading to their business operations failing to resume after the lockdowns are lifted. The following section presents the methodology used in conducting the study, starting with the research design followed by the data collection methods used in the study.

\section{Methodology}

Research in social sciences make use of the survey research methodology a lot to obtain information from a larger population. Thus, a survey research method is descriptive research used for purposes of collecting data from a representative sample of the target population. Accordingly, a survey is defined as "any procedure in which data are systematically collected from a population or a sample thereof through some form or direct solicitation, such as face to face interviews, telephone interviews or mail questionnaires" [30].

Study questionnaires were distributed to participants through a research assistant. Questionnaire completion was done by the participants or by a research assistant recruited to assist with the collection of data. The sample was randomly selected from the passenger transport operators operating from the major bus terminuses in Harare. Since the study focuses on the impact of strategy on the survival of passenger transport operators in Harare, the sample was selected from passenger transport operators with formal organisational structures, plying both domestic and cross-border routes. An informal scan established that there are about two hundred and seventy passenger transport operators with formal structures in Harare. The businesses range in size from the micro, small and medium enterprise as well as large enterprises that include parastatal enterprises. A sample of one hundred drawn from these operators was selected randomly. However, the organizations were stratified by their size and the routes plied. Results for the study are presented in the following section.

\section{Results Presentation and Discussion}

Questionnaires were distributed to a sample of 100 passenger transport operators in Harare. 88 questionnaires were completed and returned, resulting in an 88 percent response rate. The demographic information of the participants is summarised in Table 1 below. 
Table 1. Participants' Demographic Information

\begin{tabular}{|l|l|l|l|l|}
\hline Gender & Male & Female & & \\
\hline Frequency & 64 & 24 & & \\
\hline Age & $<30$ years & $30-40$ years & $41-50$ years & $>50$ years \\
\hline Frequency & 17 & 32 & 23 & 16 \\
\hline Education & High School & Diploma & Undergraduate degree & Postgraduate degree \\
\hline Frequency & 44 & 27 & 13 & 4 \\
\hline $\begin{array}{l}\text { Duration of } \\
\text { business operations }\end{array}$ & $<1$ year & $1-5$ years & $6-10$ years & $>10$ years \\
\hline Frequency & 13 & 36 & 21 & 18 \\
\hline $\begin{array}{l}\text { Position held by } \\
\text { participants }\end{array}$ & Employee & Supervisor/Manager & Owner/Manager & Owner \\
\hline Frequency & 35 & 49 & 2 & 2 \\
\hline
\end{tabular}

Source: Primary data $(\mathrm{n}=88)$

As shown in Table 1, the majority of the study participants were male (64). In terms of age, participants were evenly spread, with the largest number (32/88) aged between 30 and 40, followed by participants aged between 41 and 50 (23/88). 44 out of the 88 participants attained high school education, followed by 27 out of 88 who had diplomas. The level of educational achievement showed that participants were not highly formally educated. It was, therefore, important to establish the duration of operations of the organisation represented by the participants that showed that the majority of the transport operators had been operating for between 1 and 5 years (36/88) and 6-10 years $(21 / 88)$.

The modal position held by participants were supervisor/managers, with 49 participants. The other significant number of participants were employees. This shows that passenger transport operators have flat structured organograms, with most of the participants being supervisors or managers who are actively involved in the daily operations of their organisation. The demographic information presented in Table 1 shows that the operations in the sector are highly informal as the operators were mainly running their enterprises as family businesses with the barest minimal organogram. However, before assessing the rest of the results, it was important to ascertain the reliability of the questionnaire instrument used to collect data. The researcher used the Cronbach alpha statistics with the results presented in Table 2 .

Table 2. Reliability Statistics

\begin{tabular}{|l|l|}
\hline Cronbach's Alpha & N of Items \\
\hline 0.735 & 15 \\
\hline
\end{tabular}

The Cronbach alpha coefficient of 0.735 is acceptable and therefore showing the results of the study are reliable since the instrument is internally consistent [31]. It is, therefore a reliable and internally consistent instrument suitable for the study, and findings are reliable.

Accordingly, the departing point for the analysis of the findings after presenting the demographic information presented in Table 1, it is important to ascertain the size of the businesses. This was important to ensure assessment of the aim of the study. Figure 1 presents results on the size of the business as measured using the number of employees of the organization that participants represented. 


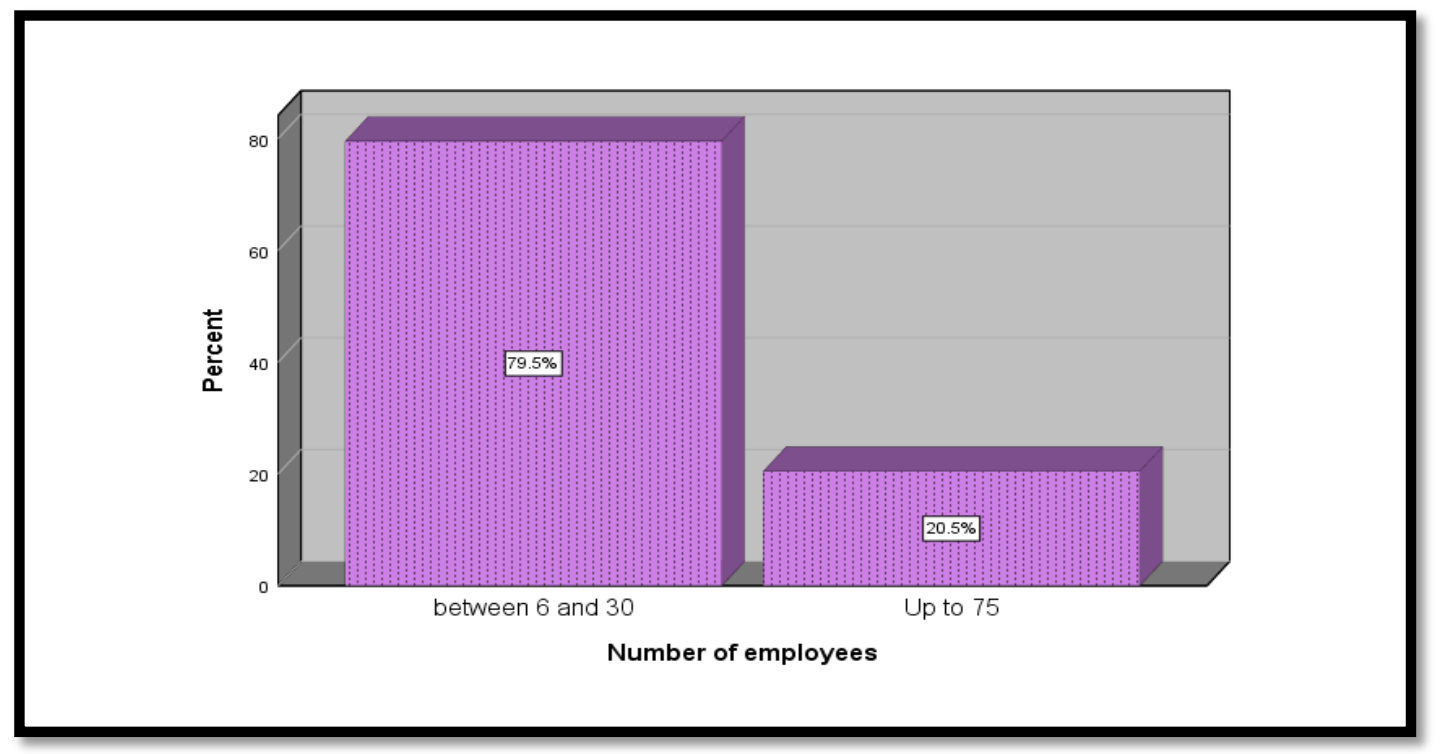

Figure 1. Number of Employees for the Passenger Transport Operators

79.5 percent of the passenger transport operators represented by the participants are classified as small enterprises, and the remaining 20.5 percent are medium-sized companies based in their number of employees [6]. The aim of the study was to assess the effects of strategy on business survival in turbulent times, such as the operating environment created during the outbreak of the COVID-19. The study therefore assessed if the passenger transport operators were practicing strategic management. Firstly, assessing whether the organisations had formalised organisational structures. The responses obtained are in Table 3 below.

Table 3. Organisation has a Formal Structure

\begin{tabular}{|l|l|l|l|l|l|}
\hline \multicolumn{2}{|c|}{} & Frequency & Percent & Valid Percent & Cumulative Percent \\
\hline \multirow{3}{*}{ Valid } & No & 14 & 15.9 & 15.9 & 15.9 \\
\cline { 2 - 6 } & Yes & 74 & 84.1 & 84.1 & 100.0 \\
\cline { 2 - 6 } & Total & 88 & 100.0 & 100.0 & \\
\hline
\end{tabular}

As shown in Table 3, 84 percent of participants represented passenger transport operators with a formal organisational structure. This shows that most of the organisations represented practiced strategic management. However, this was not conclusive, and therefore, it was necessary to establish if there was evidence of the practice of strategic management. The assessment sought to establish whether the organisations had clearly spelt out vision and missions. The results from the participants are presented in Table 4 .

Table 4. Existence of Vision and Mission statements

\begin{tabular}{|l|l|l|l|l|l|}
\hline \multicolumn{2}{|c|}{} & Frequency & Percent & Valid Percent & Cumulative Percent \\
\hline \multirow{3}{*}{ Valid } & No & 4 & 4.5 & 4.5 & 4.5 \\
\cline { 2 - 6 } & Not Sure & 18 & 20.5 & 20.5 & 25.0 \\
\cline { 2 - 6 } & Yes & 66 & 75.0 & 75.0 & 100.0 \\
\cline { 2 - 6 } & Total & 88 & 100.0 & 100.0 & \\
\hline
\end{tabular}


75 percent of the participants indicated that their organisations have vision and mission statements which shows that there is high adoption of strategic management in the passenger transport sector. However, more than 20 percent of the participants were not sure about the existence of the vision and mission statements. This was probably a result of the failure by management in the transport operators to share their strategic aspirations [9]. Therefore, the strategic vision and mission may remain an idea for the executives since it is not communicated to lower-level employees [9]. Another important component asked from the participants sought to establish whether passenger transporters were undertaking strategic planning. The results obtained are summarised in Figure 2 below.

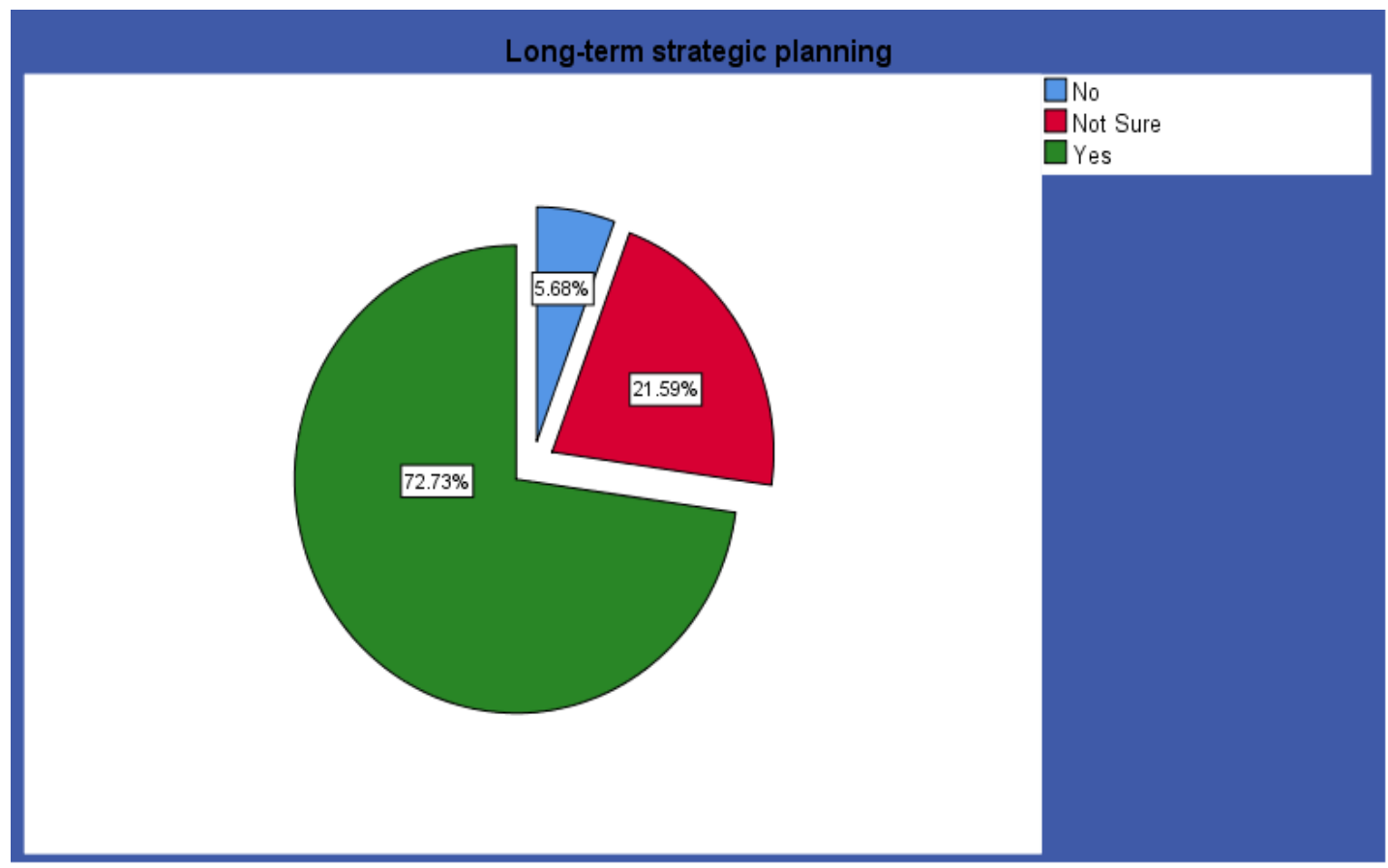

Figure 2. Practice of Long-term Strategic Planning by Passenger Transport Operators

Participants who indicated that their organisations practice long-term strategic planning were almost like the number who agreed that their institutions have clearly spelt out vision and mission statements (about 73 percent). Therefore, the results were consistent because the respondents were consistent in their responses. Strategic planning is an important part of strategic management, especially during disruptive times, as it provides strategic direction for the day-to-day operations of the business despite the status of the operating environment [18]. Participants were asked to highlight the strategies their organisations have been pursuing during the last five years, and the key strategies highlighted include the following:

a) providing fast, efficient, and safe transportation of passengers and goods, b) increasing/growing operational routes and expanding fleet,

c) improving customer service, public relations, and quality services always,

d) staff development, training, and empowerment,

e) diversifying into the trucking business.

The strategies highlighted by the participants are consistent with the need for versatility, especially in terms of pursuing diversification as a strategy during turbulent operating times, such as caused by the COVID-19 [2]. Respondents were asked to rate the importance of different strategies based on a five-point Likert scale, with the following scales: strongly disagree (1), disagree (2), not sure (3), agree (4), and strongly agree (5). Descriptive statistics of the responses obtained are summarised in Table 5. 
Table 5. Effects of Various Strategies- Descriptive Statistics

\begin{tabular}{|l|l|l|l|}
\hline & N & Mean & Std. Deviation \\
\hline Clear vision helped business grow & 88 & 4.1705 & .84719 \\
\hline Organisation has survival strategies & 88 & 4.0114 & .91594 \\
\hline Organisation has competitive strategy & 88 & 3.9773 & .87069 \\
\hline Diversification a good strategy & 88 & 3.8750 & .84163 \\
\hline Mission Statement directed employee efforts & 88 & 3.8636 & .89932 \\
\hline Cost leadership a viable strategy & 88 & 3.6591 & 1.00443 \\
\hline Valid N (listwise) & 88 & & \\
\hline
\end{tabular}

As shown in Table 5, results showed a positive effect of various strategies on the survival of businesses operating in a turbulent environment. For instance, the mean responses for the contribution of organisational vision to business growth were 4.17 , which means the average response lies between agree (4) and strongly agree (5), and the standard deviation was about 0.85 . Therefore, overall, participants agreed that a clear vision could help the business grow. Similar sentiments were obtained for the other strategies such as competitive, cost leadership, and diversification strategies. From all the highlighted strategies, diversification was commonly highlighted as a strategy that has been employed by the passenger transporters in Zimbabwe. Study participants highlighted that their companies had diversified into cargo transportation as this was regarded as an essential service during the lockdowns. Diversification was an important survival strategy during the COVID-19 induced disruptions meant to contain the pandemic [4]. The rest of the strategies may not be useful during the COVID-19 disruptive times, but they are important for business survival in times of other disruptions which may not restrict people's movements [17]. This was particularly so for passenger transportation businesses that were directly affected by the lockdown restrictions.

An examination of the correlations of these strategies is presented in Table 6. The results presented in Table 6 show the existence of significant correlations between all the various strategies. However, in terms of magnitude, some strategies are strongly positively correlated whilst others are weak-positively correlated. There are no strategies with negative correlations. It, therefore, implies that for businesses to enhance their survival during disruptive operating environments and in good times management of passenger transport operators should pursue a combination of the various strategies [24]. Passenger transport operators must deploy innovative business models to survive the disruptions such as the COVID-19 disruptions and others [23]. The rest of the relationships between the variables are shown in Table 6 below. 
Table 6. Correlations Matrix for Various Strategies

\begin{tabular}{|c|c|c|c|c|c|c|c|}
\hline & & $\begin{array}{l}\text { Clear vision helped } \\
\text { business grow }\end{array}$ & $\begin{array}{l}\text { Mission Statement } \\
\text { directed employee efforts }\end{array}$ & $\begin{array}{l}\text { Organisation has } \\
\text { competitive strategy }\end{array}$ & $\begin{array}{l}\text { Organisation has } \\
\text { survival strategies }\end{array}$ & $\begin{array}{l}\text { Diversification } \\
\text { a good strategy }\end{array}$ & $\begin{array}{l}\text { Cost leadership } \\
\text { a viable strategy }\end{array}$ \\
\hline \multirow{3}{*}{$\begin{array}{l}\text { Clear vision } \\
\text { helped business } \\
\text { grow }\end{array}$} & Pearson Correlation & 1 & $.604^{* *}$ & $.784^{* *}$ & $.546^{* *}$ & $.530^{* *}$ & $.461^{* *}$ \\
\hline & Sig. (2-tailed) & & .000 & .000 & .000 & .000 & .000 \\
\hline & $\mathrm{N}$ & 88 & 88 & 88 & 88 & 88 & 88 \\
\hline \multirow{3}{*}{$\begin{array}{l}\text { Mission } \\
\text { Statement } \\
\text { directed } \\
\text { employee efforts }\end{array}$} & Pearson Correlation & $.604^{* *}$ & 1 & $.524^{* *}$ & $.337^{* *}$ & $.691^{* *}$ & $.546^{* *}$ \\
\hline & Sig. (2-tailed) & .000 & & .000 & .001 & .000 & .000 \\
\hline & $\mathrm{N}$ & 88 & 88 & 88 & 88 & 88 & 88 \\
\hline \multirow{3}{*}{$\begin{array}{l}\text { Organisation has } \\
\text { competitive } \\
\text { strategy }\end{array}$} & Pearson Correlation & $.784^{* *}$ & $.524^{* *}$ & 1 & $.663^{* *}$ & $.576^{* *}$ & $.596^{* *}$ \\
\hline & Sig. (2-tailed) & .000 & .000 & & .000 & .000 & .000 \\
\hline & $\mathrm{N}$ & 88 & 88 & 88 & 88 & 88 & 88 \\
\hline \multirow{3}{*}{$\begin{array}{l}\text { Organisation has } \\
\text { survival } \\
\text { strategies }\end{array}$} & Pearson Correlation & $.546^{* *}$ & $.337^{* *}$ & $.663^{* *}$ & 1 & $.524^{* *}$ & $.654^{* *}$ \\
\hline & Sig. (2-tailed) & .000 & .001 & .000 & & .000 & .000 \\
\hline & $\mathrm{N}$ & 88 & 88 & 88 & 88 & 88 & 88 \\
\hline \multirow{3}{*}{$\begin{array}{l}\text { Diversification a } \\
\text { good strategy }\end{array}$} & Pearson Correlation & $.530^{* *}$ & $.691^{* *}$ & $.576^{* *}$ & $.524^{* *}$ & 1 & $.615^{* *}$ \\
\hline & Sig. (2-tailed) & .000 & .000 & .000 & .000 & & .000 \\
\hline & $\mathrm{N}$ & 88 & 88 & 88 & 88 & 88 & 88 \\
\hline \multirow{3}{*}{$\begin{array}{l}\text { Cost leadership a } \\
\text { viable strategy }\end{array}$} & Pearson Correlation & $.461^{* *}$ & $.546^{* *}$ & $.596^{* *}$ & $.654^{* *}$ & $.615^{* *}$ & 1 \\
\hline & Sig. (2-tailed) & .000 & .000 & .000 & .000 & .000 & \\
\hline & $\mathrm{N}$ & 88 & 88 & 88 & 88 & 88 & 88 \\
\hline
\end{tabular}


After the establishment of the relationship between the various strategies presented in Table 6 , it was necessary to ascertain the variables that affected the survival of the passenger transport operators in Zimbabwe during the COVID-19 disruptions. Firstly, results of the perceptions of participants on the effect of COVID-19 on business survival are presented in Figure 3.

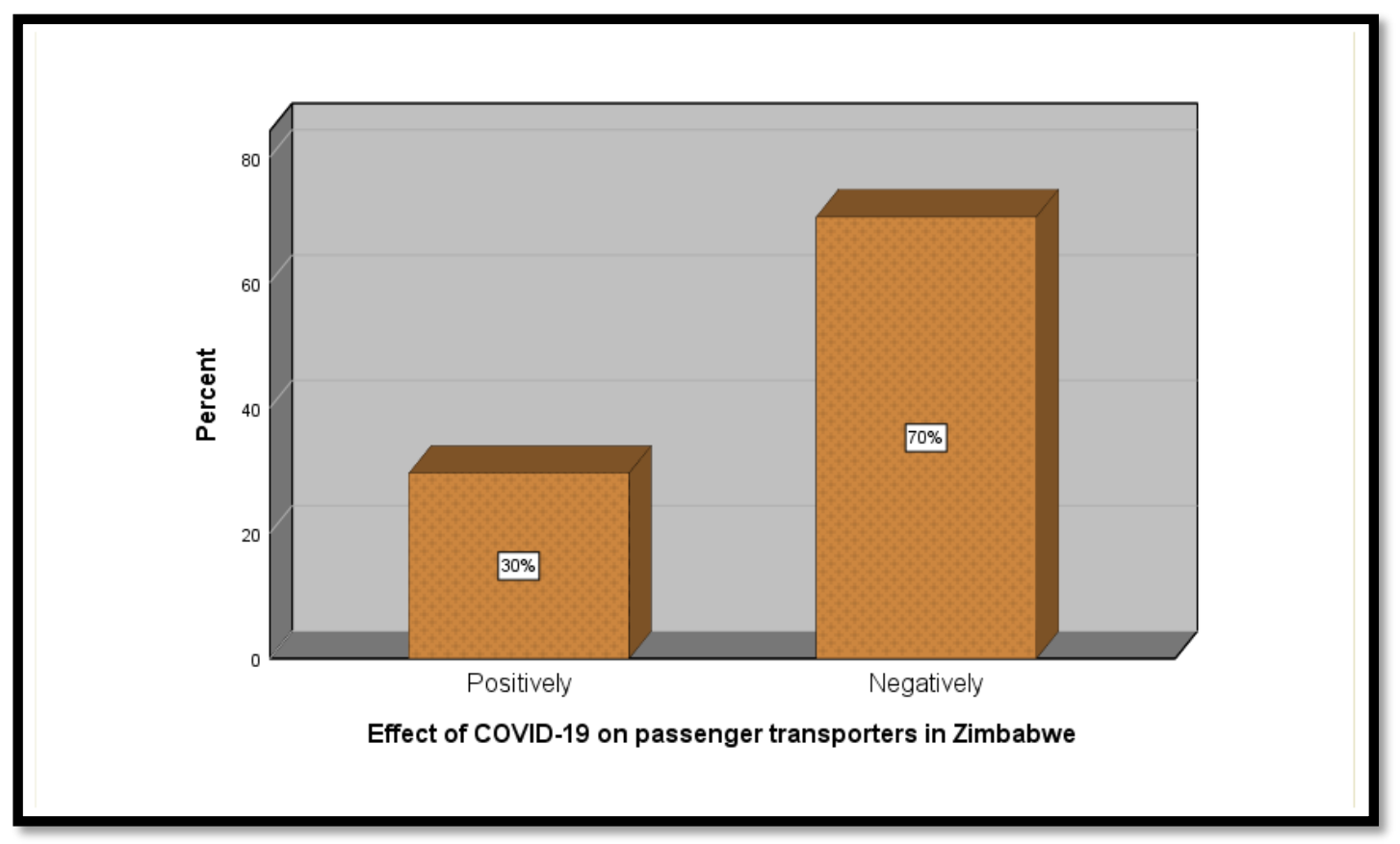

Figure 3. Effect of COVID-19 on Passenger Transporters in Zimbabwe

As shown in the figure, only 30\% of participants viewed the COVID-19 as having made positive to their business operations. The majority (70\%) viewed the COVID-19 as having negatively affected their business survival. The relationship between the independent variables and business survival (dependent variable) were assessed using a binary logistic regression model. Results of the model are presented below, starting with Table 7 .

Table 7. Classification Table

\begin{tabular}{|c|c|c|c|c|c|}
\hline & \multirow{2}{*}{\multicolumn{3}{|c|}{ Predicted }} \\
\hline & & & & & \\
\hline \multirow{2}{*}{\multicolumn{3}{|c|}{ Observed }} & \multicolumn{2}{|c|}{$\begin{array}{l}\text { Effect of COVID-19 on } \\
\text { passenger transporters in } \\
\text { Zimbabwe }\end{array}$} & \multirow{2}{*}{ Percentage Correct } \\
\hline & & & Positively & Negatively & \\
\hline \multirow[t]{3}{*}{ Step 1} & \multirow{2}{*}{$\begin{array}{l}\text { Effect of COVID-19 on } \\
\text { passenger transporters in } \\
\text { Zimbabwe }\end{array}$} & Positively & 4 & 22 & 15.4 \\
\hline & & Negatively & 2 & 60 & 96.8 \\
\hline & \multicolumn{2}{|l|}{ Overall Percentage } & & & 72.7 \\
\hline \multicolumn{6}{|c|}{ a. The cut value is .500} \\
\hline
\end{tabular}

The classification table shows that the model, before incorporating the independent variables, the model has a 72.7 percent capacity to predict to predict the effect of the COVID-19 on passenger transport operators in Zimbabwe.
After incorporating independent variables such as the number of employees and duration off business operations, among others, the model results are presented in Table 8. 
Table 8. Model Results with Variables in the Equation

\begin{tabular}{|l|l|l|l|l|l|l|l|}
\hline \multicolumn{2}{|c|}{} & B & S.E. & Wald & Df & Sig. & Exp(B) \\
\hline Step $1^{\text {a }}$ & $\begin{array}{l}\text { Duration operating as a } \\
\text { passenger transportation } \\
\text { business }\end{array}$ & -.459 & .289 & 2.517 & 1 & .113 & .632 \\
\cline { 2 - 8 } & Number of employees & .755 & .686 & 1.211 & 1 & .271 & 2.128 \\
\cline { 2 - 8 } & $\begin{array}{l}\text { Organisation has a } \\
\text { formal structure }\end{array}$ & -2.498 & 1.024 & 5.949 & 1 & .015 & .082 \\
\cline { 2 - 8 } & $\begin{array}{l}\text { Vision and Mission } \\
\text { statement }\end{array}$ & 1.267 & .770 & 2.706 & 1 & .100 & 3.550 \\
\cline { 2 - 8 } & $\begin{array}{l}\text { Long-term strategic } \\
\text { planning }\end{array}$ & -.494 & .629 & .615 & 1 & .433 & .610 \\
\hline & Constant & 3.026 & 2.269 & 1.779 & 1 & .182 & 20.614 \\
\hline
\end{tabular}

a. Variable(s) entered on step 1: Duration operating as a passenger transportation business, Number of employees, Organisation has a formal structure, Vision and Mission statement, Long-term strategic planning.

As shown in Table 8, only the existence of a formal organizational structure has a significant effect, at the $5 \%$ significance level on predicting the effects on COVID-19 on passenger transport operators. The rest of the variables did not have a significant influence on predicting the effect of COVID-19 on the survival of the passenger transport operators in Harare, Zimbabwe. Therefore, the results showed that passenger transport operators with a formal structure had the potential to innovate their business model and survive during COVID-19 [24]. The COVID-19 disruptions affected businesses in different countries differently. Given that the study found that most of the passenger transport operators in Harare to be small and mediumsized enterprises, Chinese entities were not as negatively affected as Zimbabwean entities [2]. Conclusions drawn from the study are presented in the following section of the paper.

\section{Conclusions}

Given the results presented and discussed above, the study makes the following conclusions: a) Most of the passenger transport operators in Harare, Zimbabwe, are small to mediumsized and were negatively affected by the COVID-19 disruptions to their operations.

b) There are several strategies that passenger transporters in Harare should pursue to minimise the impact of disruptions on their operations. Such strategies as diversification and cost leadership strategies.

c) The binary logistic model showed that organisations with a formal organisational structure were least likely to be negatively affected by the COVID-19 disruptions.

\section{Conflict of Interests}

The author of this manuscript does not have any conflicts of interest to declare.

\section{Acknowledgements}

The author acknowledges all participants in the study for their valuable contribution to the success of the manuscript. 


\section{References}

[1] Sahin, A. R., Erdogan, A., Agaoglu, P. M., Dineri, Y., Cakirci, A. Y., Senel, M. E., Tasdogan, A. M. (2020). 2019 Novel Coronavirus (COVID-19) Outbreak: A Review of the Current Literature. Eurasian Journal of Medicine and Oncology, 4(1), 17. https://ejmo.org/10.14744/ejmo.2020.12220/.

[2] Bouey, J. (2020). Assessment of COVID-19's Impact on Small and Medium-Sized Enterprises: Implications from China. Santa Monica, California: RAND Corporation.

https://www.rand.org/pubs/testimonies/CT524.html.

[3] OECD. (2020). Tackling coronavirus (COVID19), contributing to a global effort: The COVID-19 crisis in Montenegro. Paris: Organisation for Economic Co-operation and Development. https://www.oecd.org/dac/development-assistancecommittee/daccovid19statement.htm.

[4] Abubakar, A. (2020). Coronavirus (COVID-19): Effect and Survival Strategy for Businesses. Journal of Economics and Business, 3(2), 661-671. https://papers.ssrn.com/sol3/papers.cfm?abstract_id $=3599117$.

[5] ILO. (2020). COVID-19 and the world of work: Impact and policy responses. Geneva: International Labour Organisation (ILO). https://www.ilo.org/wcmsp5/groups/public/--dgreports/--dcomm/documents/briefingnote/wcms_738753.pdf. [6] Kapesa, T., Kufakunesu, F., \& Cheza, A. (2021). Financing the 'working of talents' Ventures: The Role of Innovative Finance. In S. D. Chingarande, J. Thondhlana, R. Madziva, \& A. H. Anderson (Eds.), Matarenda/Talents in Zimbabwean Pentecostalism Empowerment, Gender, and Development in an African Movement (pp. 49-75). Leiden: Brill. https://brill.com/view/book/9789004446670/BP0000 06.xml?language $=\mathrm{en}$.

[7] TechnoServe. (2020, June). TechnoServe. Retrieved August 19, 2020, from https://www.technoserve.org/wpcontent/uploads/2020/06/COVID-19-and-

Entrepreneurs-Supporting-Business-Survival-andRecovery-20200601.pdf.

[8] Wiley Online Library. (2020). Wiley Online Library: Zimbabwe: Coronavirus Lockdown.
Retrieved August 24, 2020, from https://onlinelibrary.wiley.com/doi/10.1111/j.1467825X.2020.09393.x.

[9] David, R. F. (2011). Strategic Management: Concepts and Cases $\left(13^{\text {th }}\right.$ ed.). New York: PrenticeHall.

http://www.mim.ac.mw/books/David\%27s\%20Strat egic $\% 20$ Management $\% 20$ Concepts $\% 20$ and $\% 20$ Cas es\%2013e\%20.pdf.

[10] Thompson, A.A., Strickland, A.J., and Gamble, J.E. (2007). Crafting and Executing Strategy: The Quest for Competitive Advantage: Concepts and Cases. 15 ${ }^{\text {th }}$ Edition, McGraw-Hill Irwin Publisher, New York.

https://www.scirp.org/\%28S\%28vtj3fa45qm1 ean45v vffcz55\%29\%29/reference/referencespapers.aspx?re ferenceid $=2584669$.

[11]Beckman, S., \& Rosenfield, D. (2008). Operations strategy: competing in the $21^{\text {st }}$ century. Boston, Mass. McGraw-Hill, Irwin. https://www.amazon.com/Operations-StrategyCompeting-Rosenfield-2008-0101/dp/B01K3HSQMS.

[12] Bozkurt, Ö.Ç., \& Kalkan, A. (2014). Business Strategies of SME's, Innovation Types and Factors Influencing Their Innovation: Burdur Model. Ege Academic Review, 14, 189-198. https://econpapers.repec.org/article/egejournl/v_3a1 4_3ay_3a2014_3ai_3a2_3ap_3a189-198.htm.

[13] Ololube, N. P., Aiya, F., Uriah, O. A., \& Ololube, D. O. (2016). Strategic Planning: A Universal Remedy for the Successful Management of $21^{\text {st }}$ Century University Education (UE). Management, 6, 76-88.

http://article.sapub.org/10.5923.j.mm.20160603.03.h tml.

[14] Sumer, K., \& Bayraktar, C.A. (2012). Business Strategies and Gaps in Porter's Typology: A Literature Review. Journal of Management and Research, 100-119. https://doi.org/10.5296/jmr.v4i3.1721.

[15]Mirabeau, L., \& Maguire, S. (2014). From autonomous strategic behaviour to emergent strategy. Strategic Management Journal, 35, 1202-1229. https://doi.org/10.1002/smj.2149. 
[16] McDowell, W. C., Harris, M. L., \& Geho, P. R. (2016). Longevity in small business: The effect of maturity on strategic focus and business performance. Journal of Business Research, 69, 1904-1908. https://doi:10.1016/j.jbusres.2015.10.077.

[17] Carlisle, Y. M., \& McMillan, E. (2017). Complex adaptive systems and strategy as learning. In Global innovation and entrepreneurship (pp. 4360). Gewerbestrasse, Switzerland: Springer International Publishing. https://DOI:10.1007/978-3319-43859-7_3.

[18]Hill, C. W., \& Jones, G. R. (2013). Strategic management: An integrated approach (10th ed.). Boston, MA: South-Western Cengage Learning, Ohio.

http://books.mcferet.com/Charles\%20W.\%20L.\%20

Hill/Strategic\%20Management_\%20An\%20Integrat ed\%20\%28868\%29/Strategic\%20Management_\%20 An\%20Integr\%20-

\%20Charles\%20W.\%20L.\%20Hill.pdf.

[19]Christensen, C. M. (1997). The Innovator's Dilemma: When New Technologies Cause Great Firms to Fail. Boston, Massachusetts: Harvard Business School Press.

https://www.hbs.edu/faculty/Pages/item.aspx?num= 46.

[20]DaSilva, C. M., Trkman, P., Desouza, K., \& Lindič, J. (2013). Disruptive technologies: a business model perspective on cloud computing. Technology Analysis \& Strategic Management, 25(10), 11611173. https://10.1080/09537325.2013.843661.

[21]Downes, L., \& Mui, C. (1998). Unleash the Killer App - digital strategies for market dominance. Boston: Harvard Business School Press. https://hbswk.hbs.edu/archive/unleashing-the-killerapp-digital-strategies-for-market-dominance.

[22] Majumdar, D., Banerji, P. K., \& Chakrabarti, S. (2018). Disruptive technology and disruptive innovation: ignore at your peril! Technology Analysis \& Strategic Management, 30(11), 1247 1255.

https://www.tandfonline.com/doi/abs/10.1080/09537 325.2018 .1523384 .

[23] Christensen, C. M., Bartman, T., \& Van-Bever, D. (2016). The hard truth about business model innovation. MIT Sloan Management Review, 58(1),
31-45. https://sloanreview.mit.edu/article/the-hardtruth-about-business-model-innovation/.

[24]Drejer, A. (2017). The Effects of Disruption on Strategic Management: Illustrated by the case study of a Danish SME. In $7^{\text {th }}$ Annual International Conference on Business Strategy In the Age of Disruption. Aalborg, Denmark: BizStrategy2017. https://www.semanticscholar.org/paper/The-Effectsof-Disruption-on-Strategic-Management\%3ADrejer/68584c947bf79d59fefc4f19a43cd3966885f28 c.

[25] KPMG. (2016). Succeeding in disruptive times: Three critical factors for business transformation success. KPMG Global Transformation Study. KPMG International Cooperative. https://assets.kpmg/content/dam/kpmg/pdf/2016/06/ Succeeding-in-disruptive-times.pdf.

[26]Lichy, J., \& Birch, C. (2016). Do universities need to re-think their business models in a rapidly changing world? In Innovative business education design for 21st-century learning (pp. 111-130). Gewerbestrasse, Switzerland: Springer International. https://DOI:10.1007/978-3-319-32622-1_9.

[27] Charbonneau-Gowdy, P. (2017). Moving outside the box: Researching e-Learning in disruptive times. Electronic Journal of e-Learning, 15(1), 59-69. https://researchers.unab.cl/en/publications/movingoutside-the-box-researching-e-learning-indisruptive-times.

[28] Kaplan, A. M., \& Haenlein, M. (2016). Higher education and the digital revolution: About MOOCs, SPOCs, social media, and the Cookie Monster. Business Horizons, 59(4), 441-450. https://www.sciencedirect.com/science/article/pii/S0 00768131630009X.

[29] Texila American University Module on Strategic Management. (2019). Texila American University. http://www.texilaamericanuniversity.com/dbllp/gozambia-school-of-management.html.

[30] Mathiyazhagan, T., \& Nandan, D. (2010). Survey research method. Media Mimansa, 34-45. https://citeseerx.ist.psu.edu/viewdoc/download?doi= 10.1.1.464.5585\&rep=rep1\&type=pdf.

[31] Ursachi, G., Horodnic, I. A., \& Zait, A. (2015). How reliable are measurement scales? External factors with indirect influence on reliability 
estimators: 7th International Conference on Globalization and Higher Education in Economics and Business Administration, GEBA 2013. Procedia
Economics and Finance, 20(1), 679 - 686. https://www.sciencedirect.com/science/article/pii/S2 212567115001239 . 